zgromadzenia zakonne, wierni z Krakowa, Lipnicy Murowanej i Brzeska. W homilii ks. Arcybiskup ukazał odchodzącego Kapłana - profesora i wychowawcę wielu pokoleń kapłańskich, który przez zycie przeszedł zawsze dobrze czyniąc.

Podczas liturgii ks. bp K. Nycz odczytał telegram Jana Pawła II nadesłany na ręce rektora Papieskiej Akademii Teologicznej w Krakowie ks. bpa T. Pieronka. Ojciec święty pisał w nim: „Odszedł bowiem człowiek, który był mi bliski... Umiał wielkodusznie dzielić się swą wiedzą biblijną z każdym człowiekiem, czy jako duszpasterz na parafii, czy jako profesor uniwersytetu".

Ks. infułata Stanisława Grzybka, zgodnie z jego życzeniem, pochowano na cmentarzu Najświętszego Salwatora w Krakowie w grobowcu rodzinnym.

Nad trumną przemawiali: przedstawiciel Katolickiego Uniwersytetu Lubelskiego i biblistów polskich, prorektor Papieskiej Akademii Teologicznej w Krakowie, przedstawiciele parafii w Lipnicy Murowanej i Krakowie-Woli Justowskiej oraz grona ludzi korzystających z dobroci Zmarłego Kapłana.

Odszedł człowiek dobry, który całe życie wypełnił służbą Bogu i ludziom.

Dobry Jezu a nasz Panie, daj mu wieczne spoczywanie!

Kraków

KS. TADEUSZ MATRAS

\title{
TELEGRAM OJCA ŚWIĘTEGO
}

Jego Ekscelencja

Ks. Biskup prof. dr hab. Tadeusz PIERONEK

Rektor

Papieskiej Akademii Teologicznej

w Krakowie

Z głębokim żalem przyjąłem wiadomość o śmierci Księdza Infułata Stanisława Grzybka. Odszedł bowiem człowiek, który był mi bliski. Na zawsze pozostaną w mojej pamięci spotkania z nim i nasza współpraca zwłaszcza z czasów, gdy byłem Metropolitą Krakowskim.

Dziękujemy mu dzisiaj za jego dobroć, prawość i autentyczne życie kapłańskie oraz za wielki wkład, jaki wniósł w polską myśl teologiczną. 
Umiał wielkodusznie dzielić swą wiedzą biblijną z każdym człowiekiem, czy jako duszpasterz na parafii, czy jako profesor Uniwersytetu. Wykszta1cił wiele pokoleń kapłanów i ludzi świeckich jako wykładowca na Papieskiej Akademii Teologicznej w Krakowie i na Akademii Teologii Katolickiej w Warszawie, a także w Seminariach Krakowskim i Częstochowskim. Należał do grupy cenionych i kompetentnych znawców Pisma Świętego, w którym nie tylko „,nabrał doskonałej biegłości”, jak mówi Księga Syracha $(1,3)$, ale które było dla Niego przede wszystkim utwierdzeniem wiary i pokarmem duszy.

Całe dobro duchowe, jakie dokonało się przez Jego posługę kapłańską składamy Bogu na ofiarę. „Dobry Jezu, a nasz Panie, daj mu wieczne spoczywanie” - tak modlimy się dzisiaj nad trumną zmarłego Księdza Infułata Stanisława, umocnieni głęboką nadzieją płynącą ze słów Jezusa: „Ja jestem zmartwychwstaniem i życiem. Kto we Mnie wierzy, choćby i umart, $\dot{z} y c ́$ będzie. Każdy, kto żyje $i$ wierzy we Mnie, nie umrze na wieki" (J 11,25-26).

Wszystkim wiernym uczestniczącym w liturgii pogrzebowej oraz rodzinie zmarłego z serca błogosławię.

Rzym, 26 października 1998 r.

JAN PAWEŁ II, PAPIEZ்

\section{Abp Stanisław Nowak}

Metropolita Częstochowski

\section{KAZANIE \\ WYGKOSZONE W KOLEGIACIE ŚW. ANNY W KRAKOWIE, DNIA 27 PAŹDZIERNIKA 1998 ROKU, W CZASIE MSZY ŚWIĘTEJ POGRZEBOWEJ KONCELEBROWANEJ ZA DUSZE KSIĘDZA STANISŁAWA GRZYBKA}

Wielce Czcigodni Księża Biskupi, Kapłani, Alumni, Siostry zakonne, Świeccy, przyjaciele i bliscy, środowiska uniwersyteckie z Papieską Akademią Teologiczną na czele. Rzeszo uczniów i słuchaczy zmarłego Księdza Infułata Profesora. Droga Rodzino Zmarłego.

Jakie słowo Boże odnieść do Ciebie, do Twojej śmierci, Umiłowany Księże Infułacie, nauczycielu i wychowawco pokoleń kapłanów, sióstr 